How to cite: Pandi, G., Horváth, Cs. (2019) Regradation of the Somesul Mic Riverbed. 2019 "Air and Water-Components of the Environment" Conference Proceedings, Cluj-Napoca, Romania, p. 31-38, DOI: 10.24193/AWC2019_04.

\title{
REGRADATION OF THE SOMESUL MIC RIVERBED
}

\author{
Gavril PANDI ${ }^{1}$, Csaba HORVÁTH ${ }^{1}$ 作 \\ DOI: 10.24193/AWC2019_04
}

\begin{abstract}
The riverbed regradation is the direct consequence of various physicogeographic and socio-economic factors influence. In the first group one must distinguish the characteristics of the upper hydrographic basin from that situated downstream of Cluj-Napoca. The operation of the Someşul Mic hydropower system is decisive for the evolution of the riverbeds dynamics. The relationships $h p=f(T)$ and $\mathrm{hp} 5=\mathrm{f}(\mathrm{T})$ show similarities, but also differentiation in their multiannual tendencies. In case of all three stations there were identified periods with high dynamics, but also periods of significant stability. Based on variation trends, eight distinguished periods were established at the first two stations and seven at Salatiu. By comparing the linear trends, they indicate different evolutions at all three stations and the polynomial trends show some similarities between Apahida and Salatiu stations.
\end{abstract}

Keywords. hydro energetic system, degradation, aggradation, characteristic periods, trends

\section{FACTORS THAT INFLUENCE THE RUNOFF AND THE RIVERBED DYNAMICS}

\subsection{Physico-geographic factors}

Climate conditions determine the water inflow in the river basin, and the lithology, relief, vegetation, etc. condition its movement towards the exit of the system.

The Someşul Mic hydrographic basin in its upper part is characterized by a wide variety of geological substrates. Along with metamorphic formations there are granitic intrusions and triasic deposits, with good resistance to erosion. Downstream appear Cretaceous and Paleogenic intercalations, and in the plateau area the Miocene deposits are generalized which are much more friable.

On the hard rocks a massive mountain relief was modeled, represented by the Gilău and the Muntele Mare Mountains, with altitudes up to $1700 \mathrm{~m}$ and a high relief energy. To the east, on sedimentary deposits, the relief of Someşan Plateau and the Transylvanian Plain is slightly fragmented and has a much more diminished energy.

\footnotetext{
${ }^{1}$ Babes-Bolyai University, Faculty of Geography, Cluj-Napoca, Romania, gavril.pandi@ubbcluj.ro hcsaba@gmail.com
} 
Of the climatic factors, the precipitation regime determines genetically the variation in runoff. The richest period of rainfall is from May to August, and the lowest is recorded during the winter. Due to the high capacity dams in the upper catchment, the rain water is retained, so the runoff is mainly determined by the quantities of water released by the hydropower plants. The extreme temperatures are recorded in July $\left(12-20^{\circ} \mathrm{C}\right)$, respectively in January $\left(-6 \ldots-3^{\circ} \mathrm{C}\right)$, so in summer there are higher water loses due to evaporation and in winter, a significant quantity of water is retained in the ice formations on the rivers.

The influence of the physico-geographic factors is significant only in the middle and lower part of the Someşul Mic River basin, downstream of the hydro-energetic system.

\subsection{Socio-economic factors}

The hydro-energetic system is the most important runoff influencing factor and implicitly of riverbed dynamics, generally the damming has dramatic hydrological, morphological and ecological influence (Best, 2019). The system has been commissioned in two stages 1968-1980 and 1980-1990 (Şerban, 2007). There are four large dams (Fântânele, Tarniţa, Someşul Cald, Gilau I) and other smaller ones (Gilău II, Floresti I and Floresti II).

The water energy is redeemed in the Mărişelu underground hydroelectric power plant and in seven others small ones, located at each dam downstream, all are peak plants regarding their operation regime. This operation mode determines large and sudden variations in runoffs along the Someşul Mic, which is reflected in the dynamics of the riverbed.

Of the socio-economic factors the cities along the river also must be mentioned. These urban areas have landscaped banks, and in Cluj-Napoca there are several bottom sills, which increase the stability of the riverbed and diminish its dynamics.

\section{DATABASE AND METHODS}

Runoff is monitored along the Somesul Mic River, at three hydrometric stations: Cluj, Apahida and Salatiu.

The three hydrometrical stations control characteristic sections of the river, not only in terms of runoff formation, but also in terms of socio-economic factors (Table 1). Thus:

- the Cluj station is the first downstream of the Someşul Mic Hydro Power System and thus suffers the direct influence of discharges passing through the hydroelectric power plants.

- Apahida is located upstream of the main tributaries which bring significant water supply from the Somes Plateau and the Transylvanian Plain. It is also downstream of the city of Cluj-Napoca, the most important socio-economic center in the basin. 
- the Salatiu station measures the discharge near the confluence with Someşul Mare River.

The physico-geographic and socio-economic factors, by determining the runoff regime, also influence the riverbed dynamics. From the geomorphological and hydrological analysis methods, regarding the riverbed's regradation, the analysis of the water level and the maximum depth variation has been chosen. These elements are present at each discharge measurement. If the water stage and depth are reported against a stable level - the graphic zero level - the difference between them indicates the vertical variation of the thalweg.

Table 1. Morphometric characteristics

\begin{tabular}{|c|c|c|c|c|c|}
\hline $\begin{array}{c}\text { Hydrometric } \\
\text { station }\end{array}$ & $\begin{array}{c}\text { A } \\
\left(\mathrm{km}^{2}\right)\end{array}$ & $\begin{array}{c}\mathrm{Hm} \\
(\mathrm{m})\end{array}$ & $\begin{array}{c}\text { L am. } \\
(\mathrm{km})\end{array}$ & L av. (km) & $\begin{array}{c}\text { Plan '0" G } \\
(\mathrm{m})\end{array}$ \\
\hline Cluj & 1194 & 977 & 90 & 88 & 346.59 \\
\hline Apahida & 1851 & 802 & 113 & 65 & 297.44 \\
\hline Salatiu & 3588 & 604 & 170 & 8 & 236.56 \\
\hline
\end{tabular}

A - catchment area, $\mathrm{H}_{\mathrm{m}}$ - catchment mean altitude, $\mathrm{L}_{\mathrm{am}}$ - river length upstream,

$\mathrm{L}_{\mathrm{av}}$ - river length downstream, Plan "0" G - graphic zero level

For the construction of the $\mathrm{hp}=\mathrm{f}(\mathrm{T})$ and $\mathrm{hp} 5=\mathrm{f}(\mathrm{T})$ graphs, one discharge measurement was chosen from each month of the 1966-2005 period. The hp variation illustrates the aggradation, respectively the degradation of the riverbed. The $\mathrm{hp} 5$ charts (moving average for five $\mathrm{hp}$ values) eliminate residual variations and show a more realistic variation trend. From the graphs one can extract the characteristic periods, the general trends of evolution, eventual harmonic variations and residual evolutions.

\section{RESULTS}

At the three analyzed stations, the hp variations show similarities, but also differences over time. Although the distances between them are not too great, the influences of various factors converge or diverge in the station sections. The general tendencies of the riverbed regradation do not fully correspond to the specialized literature, which mentions typically degradations of the river sectors downstream of dams (Juracek, 2001; Ichim \& Rădoane, 1986).

\subsection{Riverbed dynamics at Cluj-Napoca hydrometric station}

The first station at Cluj-Napoca, with an erosion-resistant lithology, is located immediately downstream of the hydro-power system. The hydrometric section and the related sector are relatively stable, stabilized by a powerful spill on Someşul Mic River, at approximately one kilometer downstream. For this reason, the maximum amplitude of the thalweg oscillations does not exceed $80 \mathrm{~cm}$.

The period with the strongest oscillations is observed after 1973, when the Mărişel power station (Pop, 1996), the most powerful hydroelectric system, was 
put into operation. Strong impulses, with up to $60 \mathrm{~m}^{3} / \mathrm{s}$ discharge, have produced significant vertical dynamics for over 10 years. After that there is a noticeable stabilization, the oscillations not exceeding $40 \mathrm{~cm}$ (Fig. 1).

In the studied time interval, eight characteristic periods were distinguished: three of aggradation, three of degradation and two of stability. Noteworthy is the relative stabilization after 1984 .

The linear trend is almost horizontal, indicating a general balance between degradation and aggradation. The sixth-grade polynomial trend shows a higher oscillation at the beginning of the interval.

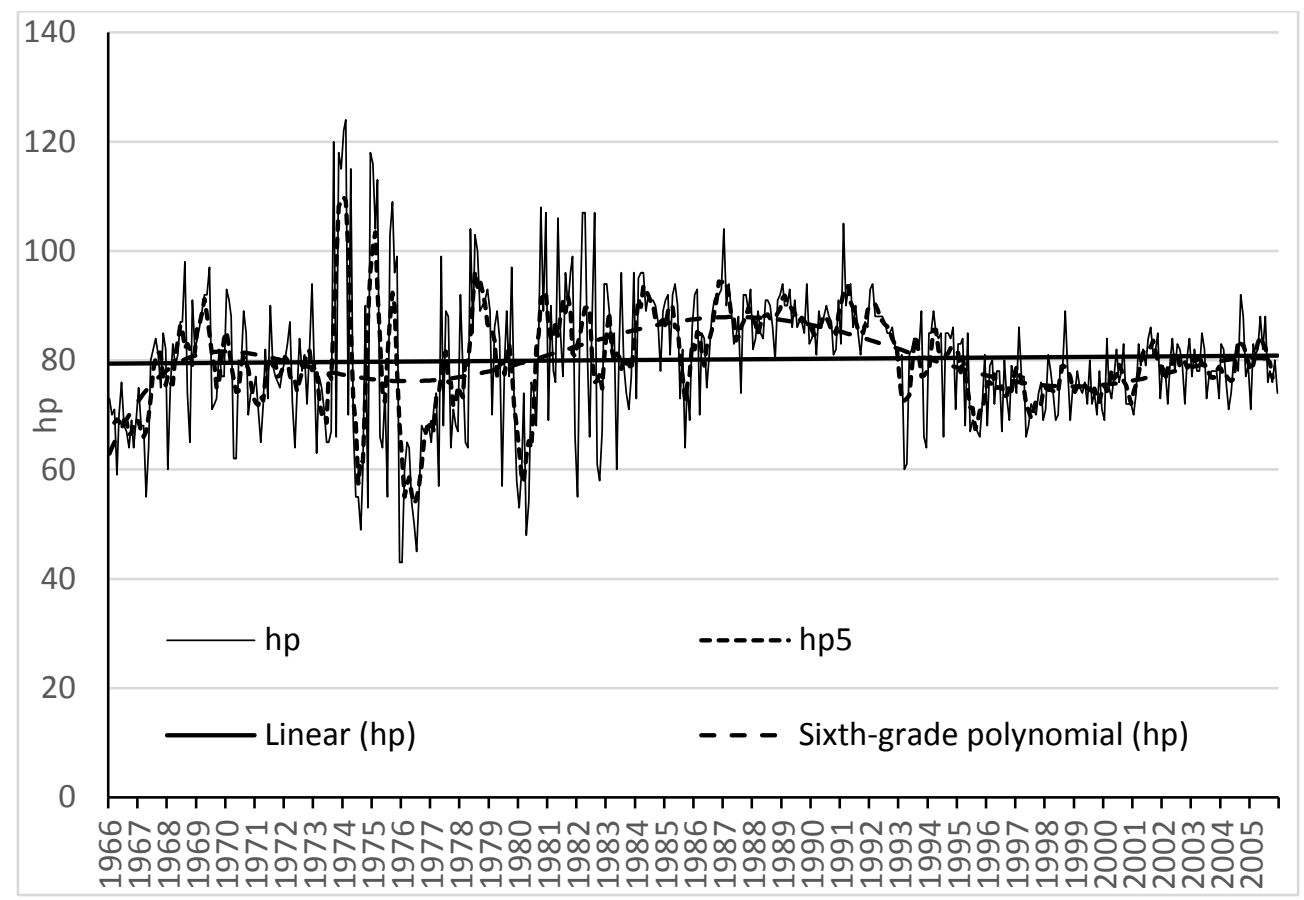

Fig. 1. River bed dynamics at Cluj-Napoca station

\subsection{Riverbed dynamics at Apahida hydrometric station}

Positioning the stream gage in the immediate vicinity of a road bridge contributes to the destabilization of the cross section. Bridge consolidation works, building a funicular to perform discharge measurements and the renewal of the stream gage contributed to deformations of the $h p=f(T)$ graph (Fig. 2).

Between the years $1984-1988$ there is a period of very high oscillations. Amplitudes of over $150 \mathrm{~cm}$ are inexplicable and must be interpreted as residual evolutions. Prior to this period, the amplitude of the thalweg oscillations remains below one meter. After the 1975 flood, near the bridge, a bottom threshold was built, its influence can be observed in the diminution of the oscillations, compared to the previous period. After 1988 the dynamics of the bed became insignificant, seems like a relative balance was achieved in the stream gage sector. 
The graph allowed the distinction of eight characteristic periods. Of these, two are aggradation, three of degradation, and also three represent relative stability. It is noted the long, 11-year period of stability, between 1989-1999, followed by a slight degradation tendency.

The linear trend indicates a slight degradation, and the sixth-grade polynomial has balanced oscillations, even in the maximum instability period between 19841988.

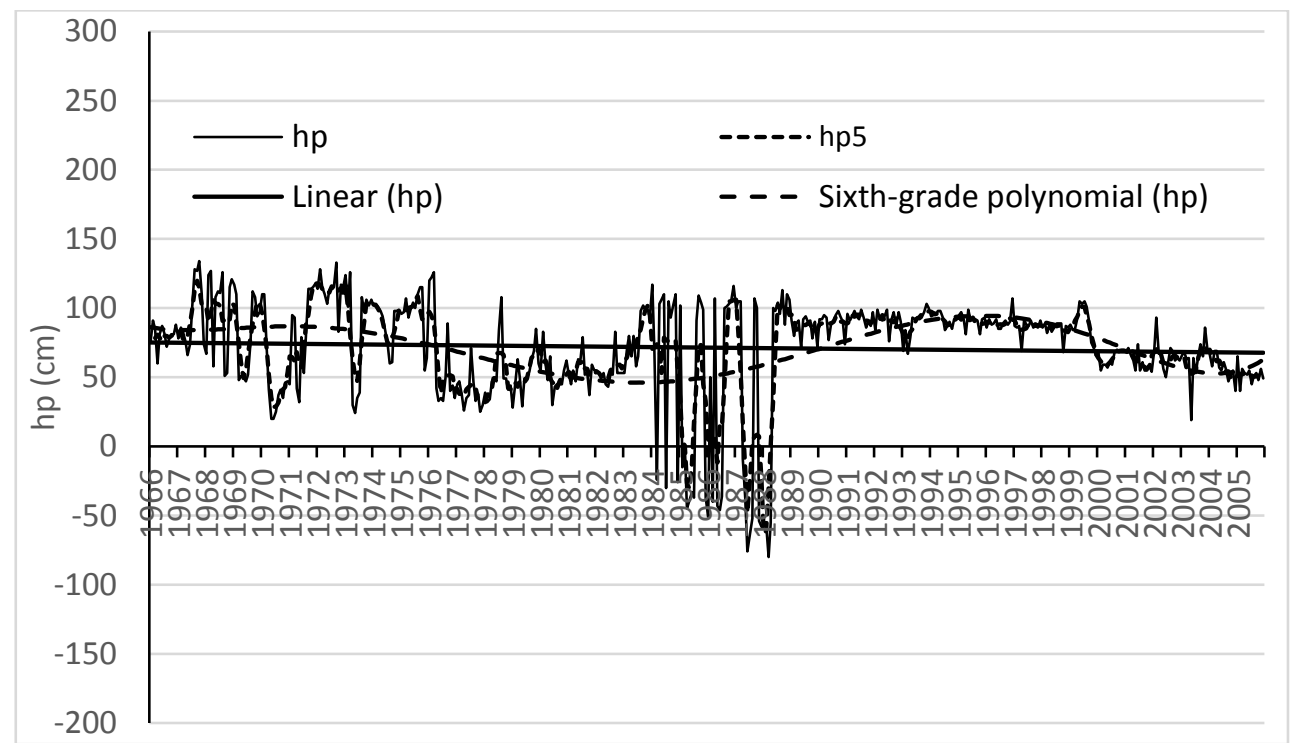

Fig. 2. River bed dynamics at Apahida station

\subsection{Riverbed dynamics at Salatiu hydrometric station}

Salatiu is the last station of the Someş Mic River, it is located at only eight $\mathrm{km}$ from the confluence with Someşul Mare. Here we observe a period very similar to that of Apahida. Between 1983 and 1988, the very strong oscillations of the thalweg has no explanation, the oscillation amplitudes in this interval exceed $70 \mathrm{~cm}$ (Fig. 3).

The dynamics of the thalweg are within reasonable limits between 1966-1987. The construction of longitudinal dykes after the 1975 flood did not influence significantly the riverbed dynamics.

After 1988, there are still four more years, with high oscillation values, but the minimum hp values stop at $25 \mathrm{~cm}$. Since 1993, the riverbed has stabilized significantly, only in the last two years has been observed a degradation trend.

Seven significant periods were distinguished: two of aggradation, three of degradation, and two of stability. If the amplitude of the oscillations is not taken into account, the period 1994-2003 can be seen as a relatively stabile period.

The linear trend is ascending, unlike the other two upstream stations and contrary to the general tendencies of the riverbed evolution downstream of the 
dams (Juracek, 2001). It should be noted, however, that here the distance from the hydropower system is significant, over $100 \mathrm{~km}$.

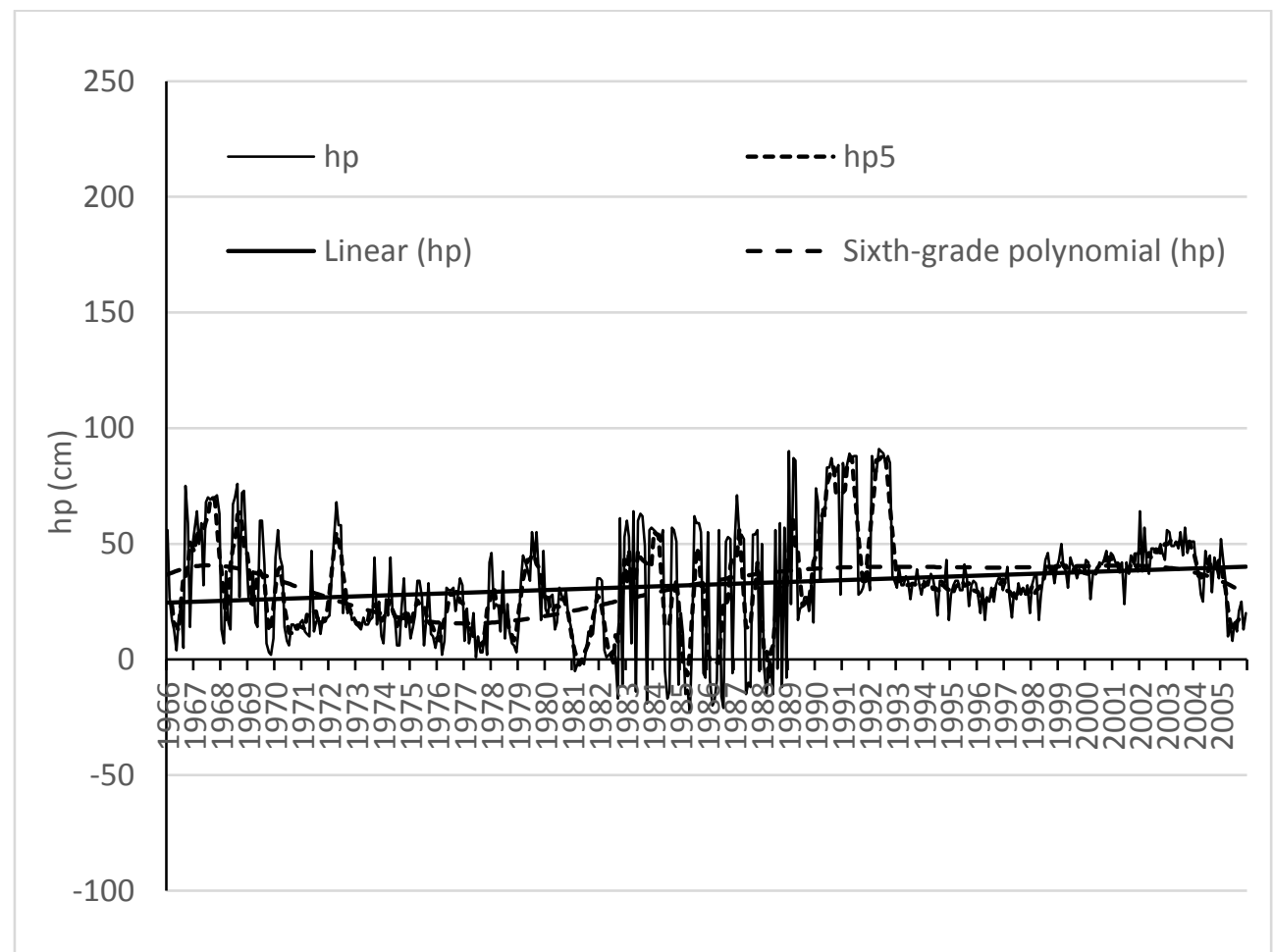

Fig. 3. River bed dynamics at Salatiu station

The polynomial trend shows larger amplitudes at the beginning of the analysis period. After the maximum instability period between 1983 and 1988 the magnitude of variations decreases significantly (Table 2).

Table 2. Characteristic periods of the riverbed regradation

\begin{tabular}{|c|c|c|c|c|c|}
\hline $\begin{array}{c}\text { Cluj } \\
\text { Time } \\
\text { interval }\end{array}$ & $\begin{array}{c}\text { nr. years } \\
\text { regradation } \\
\text { direction }\end{array}$ & $\begin{array}{c}\text { Apahida } \\
\text { Time } \\
\text { interval }\end{array}$ & $\begin{array}{c}\text { nr. years } \\
\text { regradation } \\
\text { direction }\end{array}$ & $\begin{array}{c}\text { Salatiu } \\
\text { Time } \\
\text { interval }\end{array}$ & $\begin{array}{c}\text { regradation } \\
\text { direction }\end{array}$ \\
\hline $1966-70$ & 5 A & $1966-67$ & $2 \mathrm{~S}$ & $1966-67$ & $2 \mathrm{~A}$ \\
\hline $1971-75$ & 5 D & $1968-69$ & $2 \mathrm{D}$ & $1968-70$ & 3 D \\
\hline $1976-78$ & 3 A & $1970-71$ & $2 \mathrm{~A}$ & $1971-82$ & $12 \mathrm{~S}$ \\
\hline $1979-80$ & 2 D & $1972-81$ & $10 \mathrm{~S}$ & $1983-92$ & $10 \mathrm{~A}$ \\
\hline $1981-83$ & 3 A & $1982-83$ & $2 \mathrm{~A}$ & 1993 & $1 \mathrm{D}$ \\
\hline $1984-91$ & 8 S & $1984-88$ & 5 D & $1994-03$ & $10 \mathrm{~S}$ \\
\hline $1992-94$ & 3 D & $1989-99$ & $11 \mathrm{~S}$ & $2004-05$ & $2 \mathrm{D}$ \\
\hline $1995-05$ & $11 \mathrm{~S}$ & $2000-05$ & 6 D & & \\
\hline
\end{tabular}

A-aggradation, D-degradation, S-stability 


\subsection{Trends comparison}

Compared to the almost horizontal linear tendency in Cluj, Apahida is characterized by a descending trend (Fig. 4). It is in line with the tendencies at Mera, Borşa and Luna de Sus stations in the Someşan Plateau (Pandi \& Sorocovschi, 2009). The upward trend from Salatiu may be related to the proximity of Somesul Mare confluence, the more powerful river dominating the areas morphologic evolution.

Linear trends suffer the influence of different runoff formation conditions, in the upper basin - mountainous, respectively hilly in the inferior. At the same time along the river, with distance, the influence of hydropower waves is diminished.

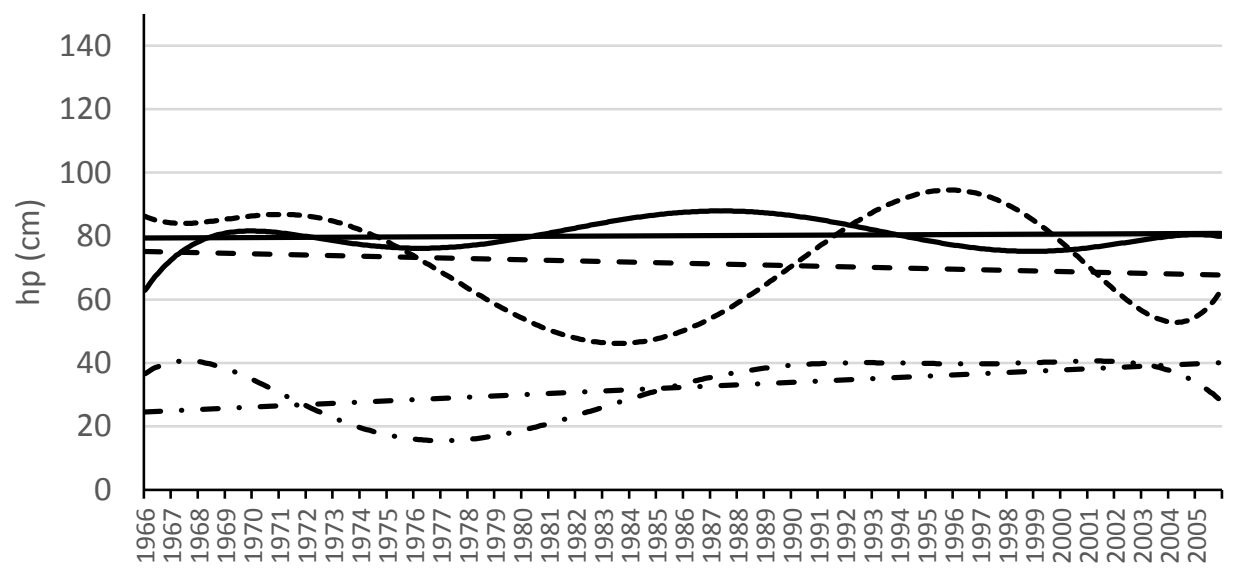

Fig. 4. Linear and polynomial trends at the three stations

Cluj-Napoca - continuous line, Apahida - dashed line, Salatiu - dotted line

The sixth-grade polynomial trends did also not indicate a synchronization between the three stations. Apahida and Salatiu are somewhat similar, but Cluj has totally different evolutions. Minimum amplitudes are found in Cluj, and the highest at Apahida station. The 40-year period proves to be too short to identify harmonic oscillations.

The causes of these variations in trends must be sought in the differential influence of the physico-geographic and socio-economic factors in the upper and lower part of the catchment, which determine the various regradation forms of the riverbed.

Trends can also be compared by evaluating the frequency over the 40 years. It is noted that at all stations the stability periods are predominant (19-23 years). This differentiates the Someşul Mic River from other areas of Romania where the degradation of the riverbed prevails (Rădoane et all., 2010). Big differences exist in the ascending years, where Cluj and Salatiu have over 10 years, and Apahida only four. Also, the descendant trend is differentiated, at Salatiu only 6 years against the 10 years at Cluj and 13 at Apahida (Fig. 5). 


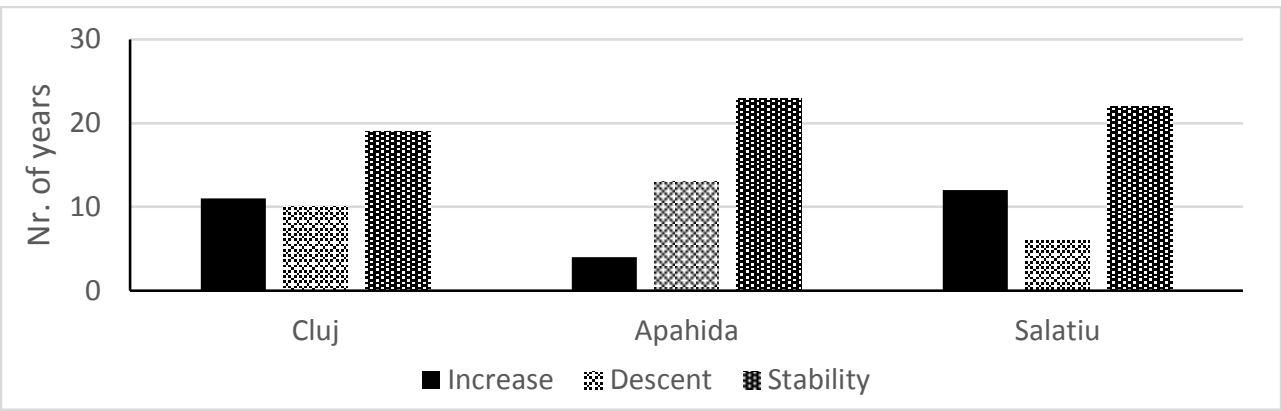

Fig. 5. Number of years with different trends

\section{CONCLUSIONS}

The chosen analysis method allows us to evaluate long-time evolution of the riverbed - in our case 40 years. The Someşul Mic hydro-power system has the most influence on the riverbed dynamics, the system creates waves with up to $60 \mathrm{~m}^{3} / \mathrm{s}$ runoff, which are determinants on the riverbed evolution along the river.

The charts show differentiated evolutions in the three sections. At Apahida and Salatiu there is a period of very high oscillations. In the second part of the analysis interval at all stations there is a stabilization of the riverbeds, the regradations diminishing their amplitudes. Summing up the years with similar trends, we can see that at all stations the years with relative stability of the riverbed predominate.

Linear and polynomial trends of the charts have different form, reflecting the various influencing factors which play a role in the evolution and formation of river runoff and riverbed regradation.

\section{REFERENCES}

1. Ichim I., Rădoane M. (1986), Efectele barajelor în dinamica reliefului. Abordare geomorfologică, Edit. Academiei, București

2. Juracek K. (2001), Channel bed elevation changes downstream from large reservoirs in Kansas, U.S., Geological Survey, Report 01-4205

3. Best, J. (2019) Anthropogenic stresses on the world's big rivers. Nature Geoscience 12, pages 7-21 (2019) https://doi.org/10.1038/s41561-018-0262-x

4. Pandi G., Sorocovschi V. (2009): Dinamica verticală a albiei râurilor din Dealurile Clujului şi Dejului, Riscuri şi catastrofe nr.7, p.218-226, Ed. Casa cărţii de ştiinţă, Cluj

5. Pop G. (1996): România. Geografie hidroenergetică, Edit.Presa universitară clujeană, Cluj

6. Rădoane Maria, Pandi G., Rădoane N. (2010): Contemporary Bed Elevation Changes from the Eastern Carpathians, Carpathian Journal of Earth and Environmental Sciences, 5/2, Baia Mare

7. Șerban Gh. (2007), Lacurile de acumulare din bazinul superior al Someșului Mic Studiu hidrogeografic, Edit.Presa Universitară Clujeană, Cluj 